Aliyev B.A., Kalashova Kh.Kh.•

DOI: 10.25108/2304-1730-1749.iolr.2018.56.6-20

\title{
Normative legal aspects of international terrorism and the fight against it
}

\begin{abstract}
Terrorism is one of the most serious threats to social security and public order. Terrorism is a large scale committed against social security and public order, and also as a result of the massive killing of people, the massive destruction of material and moral values, and the violation of the normal course of public life by the authorities and governing bodies between different social groups, even different societies, states, and even societies of the same society, who have the right to violate their normal work, condemn the lives and health of citizens, paralyze the public goodwill of citizens, make decisions on organizational and managerial decisions, is one of the most dangerous forms of criminal offenses against social security and public order accompanied by hostility is one of the most dangerous of beliefs.
\end{abstract}

Ensuring international security first of all requires compliance with international law and rule of law. The achievements of the international community in the fight against international terrorism are solved within the framework of appropriate efforts aimed at the implementation of international law and rule of law. Crime and aggression crimes against humanity are included in the jurisdiction of the International Criminal Court. International terrorism included in international crimes is also part of the International Criminal Court's jurisdiction. According to the status of the International Criminal Court, the application of the

\footnotetext{
"Aliyev Bakhtiyar Abdurahman - PhD in Law, Associate Professor, Head of Department "Legal provision of state security" of the İnstitute of Law and Human Rights of the National Academy of Sciences of the Republic of Azerbaijan (Azerbaijan). E-mail: antiterror-baku@mail.ru

Kalashova Khayala Khaqani qizi - Senior Research Fellow of "The legal provision of state security" Department of the Institute of Law and Human Rights of the National Academy of Sciences of the Republic of Azerbaijan (Azerbaijan). E-mail: xayala_kalashova@yahoo.com
} 
principles of universal jurisdiction against international crimes, including international crimes, is envisaged. International crime of terrorism creates serious threats to international peace and security. The threat of terrorism is global for all humanity and it can be effective only to deal with joint efforts. These efforts are carried out at sub-regional, regional, national and universal levels. At present, regional systems for the prevention of international terrorism practically operate in all regions of the world on the basis of the Ten Tranche Universal Conventions, eight EU conventions and other conventions, declarations and protocols.

Combating terrorist crimes is extremely problematic. Law enforcement agencies are the main organizers who expose small numbers of criminals. It is understood during the study that terrorists are more likely to commit international crimes against humanity in public places where more and more people are concentrated.

Keywords: terrorism; fight; legal services; illegal turnover; crime; antiterrorism activity.

As a result of the study of combating methods, such savings are generated that terrorists often seek safe conditions to carry out their deeds without any hindrance and use remote techniques and techniques. In modern conditions, terrorism activity is expanding its activities in close contact with international terror centers and organizations without recognizing state borders. One of the most pressing issues currently facing the world community is the formulation of practical measures against terrorism. The importance of fighting international terrorism crimes was reflected in the Declaration adopted at the Millennium Summit held in New York on September 6-8, 2000 with the participation of 192 countries [4, p.39].

The document notes that the co-ordination of the state's activities in the fight against international terrorism, the international community's commitment to the conflict and the United Nations' contribution to terrorism in the future. Currently, 
the United Nations is implementing a planned and concrete action to prevent international terrorism. For this purpose, an international tribunal was established in 1998 within the United Nations.

One of the key issues of his activity is the provision of legal services for crimes related to international terrorism. The International Criminal Tribunal against international terrorism seeks to fight seriously without damaging human rights and freedoms within the framework of international law [6, p.83].

At present, the world community has the means to effectively counteract the international terrorism offense by complying with the legal norms in accordance with the provisions of the Declaration of the Millennium adopted at the General Assembly Summit on 6-8 December 2000. At the same time, regional systems have been set up to combat international terrorism, guiding the seven Conventions signed.

The fight against international terrorism requires a comprehensive approach to this problem, including the legal, political, economic, diplomatic and military efforts of the world community. It should also take into account the fact that international terrorism is in close contact with transnational organized crime groups dealing with laundering money, spreading drugs, and trafficking in arms, ammunition, chemical and biological and other materials [7, p. 26].

The US Department of State has adopted a program to combat terrorism. 200 academic publications devoted to terrorism were published in that country during the year. The political leadership of the United States and Western Europe first of all focuses on the legal basis for the fight against terrorism and its improvement. Legal protection against anti-terrorism activity is one of the crucial factors that can be countered internationally and internationally. The main principles of the fight against terrorism are the following: legitimacy, first-degree measures to prevent terrorism, the need to bring the perpetrators to justice, the protection of human rights of persons at risk as a result of terrorist acts, the application of minimum 
discrimination against terrorists, and counter-terrorist operations the implementation of a single administration from the center to the forces and means, and so on. Strengthening the law against this type of crime is one of the most important issues [5, p.203].

The Republic of Azerbaijan is the coordinator of resolutions adopted by the UN General Assembly on various issues that concern the international community. The National Delegation has made some resolutions on its own initiative. Thus, at the 58-60th session of the UN Human Rights Commission, a draft resolution entitled 'Missing Persons' proposed by the Azerbaijani delegation was proposed. The provisions of this resolution have been adopted on the basis of international humanitarian law and aimed at attracting international community's attention to this important issue.

For decades, some mechanisms and methods have been applied in the fight against terrorism by the countries of the world and Azerbaijan (creation of special anti-terror forces, strengthening of protection of special dangerous and important objects, preparation of negotiable technologies for release of hostages, etc.).

It should be noted that the Interpol organization within the United Nations plays an important role in the fight against international terrorism. In our view, it is crucial to establish the principles of combating terrorism in the legislation. Because international terrorism, which is a type of international crime, can provoke excessive public action, escape from legitimacy, reduce confidence in the state, undermine international peace and security, breach the interests of the international community, and so on.

One of the important conditions for hindering the growth of terrorism and fighting against it is the national legislation in this area with international standards. Regarding the tactics and technology of combating terrorism, it should be noted that for each anti-terrorist service, these are specific rules. However, these tactics and technologies have been developed by many private service agencies 
over many years of practical action and have never been opened or kept secret $[8$, p.66].

Multilateral cooperation against terrorism has largely been formed in the last 50 years. At the global level, it is administered under the auspices of the United Nations and its specialized agencies on the basis of universal convention and protocols adopted in the field of combating terrorism in various aspects of land, water and air. At the same time, Resolution 1368, adopted by the United Nations, condemns terrorist attacks and states that these acts are threatening the security of the world and, in addition to expanding international cooperation in the fight against terrorism, the Security Council's no. 1269 (1999) the other conventions in all countries [9, p.1].

The Security Council has adopted Resolution no. 1373 of 28 September 2001 in accordance with Article 7 of the Charter of the United Nations. The resolution, in its entirety, is a threat to international security and has once again highlighted the right of collective and individual self-defense adopted in the United Nations Charter. The Security Council called on all states to expand cooperation to prevent terrorist acts: preventing and preventing terrorist financing; Carrying out criminal charges for collection of financial means, allowing for the implementation of terrorist acts; freezing financial assets and economic resources of those who committed and committed acts of terror.

In addition to other conditions in combating terrorism, crucial issues, such as cruelty, insistence on adequate response to terrorism, and specially equipped and trained technicians, are also decisive actions of the country's leadership [10, p.6].

Public, political parties, organizations and movements can play an important role in combating terrorism with state agencies. One of the main conditions for the fight is the elimination of all illegal militarized and armed groups. Terrorism has two major driving forces: financial and moral. The financial side is to infringe the property of another person by applying force. The spiritual side is the creation of 
the second kind of self-serving person by directing his life to the other person by giving him the freedom to do so. Effective work against terrorism requires the development and implementation of a number of organizational and practical measures [11, p. 2].

In order to strengthen the fight against terrorism, a number of criteria were implemented by $27 \mathrm{EU}$ member states. These measures include the application of the general order of arrest and freezing of accounts relating to criminals.

At the same time, a decision was made to ensure that all telecommunications, including cellular telephone information, was kept in custody for a period of time [12, p. 3]. International law provides for a comprehensive and effective system of effective remedial action against international terrorism. The institute of criminal offenses (CRRF) and the institute of mutual legal assistance on criminal cases are a common means of regulating action of international law against international terrorism. Both methods are equally efficient, and the expectation of their demands in the strict regime will help the world community with a strong commitment to the elimination of international terrorism.

\section{References}

1. Azerbaycan Respublikasinin "Terrorculuga qarsi mubarize haqqinda" Qanun [The Law of the Republic of Azerbaijan “On Combating Terrorism”]. Baku, 1999, $144 \mathrm{p}$.

2. Azerbaycan Respublikasinin Cinayet Mecellesi [Criminal Code of the Republic of Azerbaijan]. Baku, 2018, 736 p.

3. Azerbaycan Respublikasi Prezidentinin 11 may 2002-ci il tarixli serencami [Order of the President of the Republic of Azerbaijan dated May 11, 2002]. Azerbaycan qazeti ["Azerbaijan" newspaper]. Baku, 2002, 12 p. 
4. Avropa Tehlukesizliyi Xartiyasi (19 noyabr 1999-cu il Istanbulda imzalanib) Azerbaycan Respublikasinin qosulmasi barede Azerbaycan Respublikasinin 12 dekabr 2000-ci il tarixli Qanunu [Law of the Republic of Azerbaijan on December 12, 2000 'On accession of the Republic of Azerbaijan to the European Charter of Charter'] (signed on 19 November 1999 in Istanbul), Baku, 2000.

5. Nabiyev A. Beynelxalq terrorculuq [International terrorism]. Baku, 2011, $282 \mathrm{p}$.

6. "Terrorculuga qarsi mubarize haqqinda" Azerbaycan Respublikasinin Qanununun tesdiq edilmesi barede Azerbaycan Respublikasi Prezidentinin Fermani [Decree of the President of the Republic of Azerbaijan "On Approval of the Law of the Republic of Azerbaijan" "On Combating Terrorism"]. Azerbaijan Legislation Collection, No. 8, article 475, Baku, 2014.

7. "Terrorculuga qarsi beynelxalq mubarize uzre coxterefli qrup" (KMT) ["Multilateral Anti-Terrorism Group" (KMT)]. Milli seviyyede nailiyyetler [Achievements at the national level]. Baku, 2002, 75 p.

8. Walter Lacker. Kornney Terrorism. Moscow, 2003, 447 p.

9. http://mfa.gov.az/files/file/43.pdf

10. http://www.elibrary.az/docs/Journal/jrn2008_603j.htm

11. http://www.baki-xeber.com/siyaset/221.html

12. https://azertag.az/xeber/BEYNALXALQ_TERRORIZMA_QARSI_BIRG A_MUBARIZA_DOVRUN_TALABIDIR-960668. 